\title{
Characterization of KIF20A as a prognostic biomarker and therapeutic target for different subtypes of breast cancer
}

\author{
MASAKO NAKAMURA ${ }^{1,2}$, ATSUSHI TAKANO ${ }^{1-3}$, PHUNG MANH THANG ${ }^{1-3}$, BAYARBAT TSEVEGJAV ${ }^{1,2}$, \\ MING ZHU ${ }^{1,2}$, TOMOYUKI YOKOSE ${ }^{4}$, TOSHINARI YAMASHITA ${ }^{5}$, YOHEI MIYAGI ${ }^{6}$ and YATARO DAIGO $^{1-3}$ \\ ${ }^{1}$ Department of Medical Oncology and Cancer Center; ${ }^{2}$ Center for Advanced Medicine against Cancer, \\ Shiga University of Medical Science, Otsu, Shiga 520-2192; ${ }^{3}$ Center for Antibody and Vaccine Therapy, \\ Research Hospital, Institute of Medical Science, The University of Tokyo, Tokyo 108-8639; \\ Departments of ${ }^{4}$ Pathology, and ${ }^{5}$ Breast and Endocrine Surgery, Kanagawa Cancer Center; ${ }^{6}$ Molecular Pathology \\ and Genetics Division, Kanagawa Cancer Center Research Institute, Yokohama, Kanagawa 241-8515, Japan
}

Received November 11, 2019; Accepted March 6, 2020

DOI: $10.3892 /$ ijo.2020.5060

\begin{abstract}
The aim of the present study was to identify novel prognostic biomarkers and therapeutic targets for breast cancer; thus, genes that are frequently overexpressed in several types of breast cancer were screened. Kinesin family member 20A (KIF20A) was identified as a candidate molecule during this process. Immunohistochemical staining performed using tissue microarrays from 257 samples of different breast cancer subtypes revealed that KIF20A was expressed in 195 $(75.9 \%)$ of these samples, whereas it was seldom expressed in normal breast tissue. KIF20A protein was expressed in all types of breast cancer observed. However, it was more frequently expressed in human epidermal growth factor receptor 2 (HER2)-positive and triple-negative breast cancer than in the luminal type. Moreover, KIF20A expression was significantly associated with the poor prognosis of patients with breast cancer. A multivariate analysis indicated that KIF20A expression was an independent prognostic factor for patients with breast cancer. The suppression of endogenous KIF20A expression using small interfering ribonucleic acids or via treatment with paprotrain, a selective inhibitor of KIF20A, significantly inhibited breast cancer cell growth through cell cycle arrest at the $\mathrm{G} 2 / \mathrm{M}$ phase and subsequent mitotic cell death. These results suggest that KIF20A is a candidate prognostic biomarker and therapeutic target for different types of breast cancer.
\end{abstract}

Correspondence to: Dr Yataro Daigo, Department of Medical Oncology and Cancer Center, Shiga University of Medical Science, Seta-Tsukinowa-Cho, Otsu, Shiga 520-2192, Japan

E-mail: ydaigo@belle.shiga-med.ac.jp

Abbreviations: ATP, adenosine triphosphate; FBS, fetal bovine serum; DAB, 3,3'-diaminobenzidine; MTT, 3-(4,5-dimethylthiazol2-yl)-2,5-diphenyltetrazolium bromide; OS, overall survival; RNA, ribonucleic acid; TNBC, triple-negative breast cancer

Key words: kinesin family member 20A, breast cancers, biomarker, therapeutic target, oncoantigen

\section{Introduction}

Breast, lung and bronchial and colorectal cancer are the three most commonly diagnosed types of cancer among women and represent $50 \%$ of all cases. However, breast cancer alone is expected to account for $30 \%$ of all new cancer cases diagnosed among women (1). Breast cancer is a collection of conditions that have different biological properties and can arise from various genetic abnormalities. Treatment for breast cancer is based on clinical classification, such as hormone receptor [estrogen receptor (ER)/progesterone receptor $(\mathrm{PgR})]$-positive breast cancer, human epidermal growth factor receptor 2 (HER2)-positive breast cancer and triple-negative breast cancer (TNBC). Luminal type breast cancer is ER/PgR-positive and HER2-negative and accounts for 70-80\% of breast cancer cases. HER2-type breast cancer is characterized by HER2 protein expression and accounts for $15-20 \%$ of breast cancer cases. TNBC is characterized by the lack of ER, PgR and HER2 expression and accounts for $15-20 \%$ of breast cancer cases (2). Hormone therapy, including aromatase inhibitors, selective ER modulators and ER downregulators, has considerably improved the clinical outcomes of patients with ER-positive breast cancer. Tamoxifen treatment can reduce the 5 -year risk of recurrence and death by 41 and 33\%, respectively (3). Luminal A-type breast cancer is characterized by the expression of hormone receptors and has a good overall prognosis under hormone therapy. Chemotherapy is currently considered for luminal B-type breast cancer, which has a high growth potential. Moreover, HER2-targeted drugs, such as trastuzumab (Herceptin ${ }^{\circledR}$ ), pertuzumab $\left(\right.$ Perjeta $^{\circledR}$ ) and lapatinib (Tykerb ${ }^{\circledR}$ ) have improved the outcomes and survival rates of women with HER2-positive breast cancer (4).

Although differences between intrinsic breast cancer subtypes are well known, one of the issues with breast cancer treatment is that a practical 'targeted therapy' for TNBC is not widely available and the effectiveness of chemotherapy for patients with TNBC remains limited (5). Olaparib, an oral poly (adenosine diphosphate-ribose) polymerase inhibitor, is available for chemotherapy-resistant, BRCA mutation-positive, HER2-negative inoperable or recurrent breast cancer. It 
provides a significant benefit over standard therapy for patients with metastatic breast cancer having a germline $B R C A$ mutation (6). Breast cancer has historically been viewed as an immunologically silent disease. Previous clinical trials have reported that nivolumab, an anti-PD-1 antibody, has demonstrated an objective response rate of only $5-10 \%$ in patients with metastatic TNBC (7). Preclinical and clinical trials have demonstrated that low-dose induction chemotherapy or radiation followed by immune checkpoint inhibitor treatment, such as with nivolumab, may be useful for the stimulation of anticancer immune responses (8).

Prognostic biomarker tests for breast cancer are available, including Oncotype DX, Mama Print and Prosigma. However, these biomarkers test different sets of breast cancer-related genes (9). Although these diagnostic tests are typically used as prognostic markers in early-stage breast cancer, they are costly and require multiple markers (10). Therefore, simpler and easily measurable biomarkers with highly accurate assays need to be developed for the treatment of patients with breast cancer.

To identify target molecules for the diagnosis and treatment of cancer, gene expression analysis and subsequent tissue microarray analysis of solid tumor tissues have been conducted. Dozens of oncoantigens that play essential roles in the progression of various solid tumors have been isolated (11-31), including members of the kinesin superfamily, which are involved in essential mechanisms during intracellular transport and cell division in cancers. The present study focused on the genes that encode kinesin proteins that are overexpressed in the majority of breast cancers, whereas are scarcely expressed in normal tissues. During this screening process, kinesin family member 20A (KIF20A), a member of the kinesin superfamily-6, was identified as a candidate molecular target that was frequently and highly expressed in breast cancer. KIF20A possesses a conserved motor domain that binds to microtubules and couples adenosine triphosphate (ATP) hydrolysis to generate mechanical forces (32). In addition, KIF20A has a microtubule plus end-directed motility and is involved in different cellular processes, such as mitotic spindle formation, chromosome partitioning and cytokinesis (33). Previous studies have indicated that KIF20A is highly expressed in several types of human cancers, including pancreatic (34), breast (35), glioma (36), prostate (37) and bladder cancers (38). FOXM1 has been reported to regulate KIF20A expression, resulting in the promotion of cell growth. Conversely, the depletion of KIF20A has been reported to enhance the antitumor effects of paclitaxel in luminal type breast cancer cells (35). To date, it has not been completely elucidated whether KIF20A expression is related to clinical breast cancer subtypes. Furthermore, the mechanistic potential of KIF20A inhibition as a novel molecular therapy for various subtypes of breast cancer has not yet been fully investigated. Therefore, in the present study, KIF20A was characterized as a potential diagnostic and therapeutic target for different types of breast cancer.

\section{Materials and methods}

Cells lines and clinical samples. In total, 11 breast cancer cell lines (T-47D, ZR-75-1, MCF-7, AU565, SK-BR-3, HCC1599, HCC1143, HCC1937, MDA-MB-231, BT-20 and MDA-MB-468) and normal adult breast epithelial cell line
(184A1) were used in the present study. Table I details the derivation of these cells and the suppliers. All cells were grown in monolayers in the appropriate medium supplemented with $10 \%$ fetal bovine serum (FBS; Gibco; Thermo Fisher Scientific, Inc.). The cells were incubated at $37^{\circ} \mathrm{C}$ in a humidified air atmosphere with $5 \% \mathrm{CO}_{2}$, apart from the MDA-MB-468 and MDA-MB-231 cells, which were incubated with $0 \% \mathrm{CO}_{2}$. The 184A1 cells were grown in medium supplemented with EpiLife Defined Growth Supplement (Thermo Fisher Scientific, Inc.). Furthermore, 10 breast cancer or normal breast tissue samples obtained from patients who had undergone surgery at Kanagawa Cancer Center Hospital during March, 2008 to December, 2009 (Table II) were used for reverse transcription-quantitative PCR (RT-qPCR) experiments. A total of 257 formalin-fixed primary breast cancer tissues (obtained from female patients; median patient age, 57 years; age range, 28-89 years) and adjacent healthy tissues were obtained from patients at the Kanagawa Cancer Center Hospital, Japan (Table III). The clinical stage of the samples was determined according to the Union for International Cancer Control TNM classification. The present study and the use of all clinical materials were approved by individual institutional ethics committees. The project to establish tumor tissue microarrays from archival formalin-fixed and paraffin-embedded surgically resected tissues and to use the tissue microarrays for later unspecified research works was approved by the Kanagawa Cancer Center Ethics Committee with the approval no. Rin-177, 27 (September, 2010). The patients involved in the breast cancer tissue microarrays received mastectomy operations for breast cancer at Kanagawa Cancer Center Hospital from 2004 to 2006. Written comprehensive informed consent was obtained from the patients for the use of their clinical information and for specimens remaining after clinically required examinations, such as archival formalin-fixed and paraffin-embedded specimens following diagnosis.

$R T-q P C R$. Total ribonucleic acid (RNA) was extracted from the cultured cells and clinical tissues using a Maxwell ${ }^{\circledR} 16$ LEV simplyRNA Cells kit and Tissue kit (Promega Corp.), according to the manufacturer's protocol. Complementary DNA was synthesized using a ReverTra Ace ${ }^{\circledR}$ RT-qPCR lit (Toyobo). The mRNAs were quantified by RT-qPCR analysis using TaqMan ${ }^{\circledR}$ Universal Master Mix II and TaqMan ${ }^{\circledR}$ Gene Expression Assays on a StepOne Plus (Thermo Fisher Scientific, Inc.), according to the manufacturer's instructions. The reaction conditions were as follows: Initial denaturation for $2 \mathrm{~min}$ at $50^{\circ} \mathrm{C}$ and $10 \mathrm{~min}$ at $95^{\circ} \mathrm{C}$ followed by 40 cycles of denaturation $\left(15 \mathrm{sec}\right.$ at $95^{\circ} \mathrm{C}$ and $60 \mathrm{sec}$ at $\left.60^{\circ} \mathrm{C}\right)$. Each experiment was performed in triplicate. For the assays, KIF20A (Hs00993573_m1) primer was used and actin beta (ACTB; Hs01060665_g1) was run as an internal control (Thermo Fisher Scientific, Inc.).

Western blot analysis. Cells were lysed in Pierce RIPA buffer (Thermo Fisher Scientific, Inc.) that included a 1\% protease inhibitor cocktail (Thermo Fisher Scientific, Inc.). Following homogenization, the cell lysates were incubated on ice for $30 \mathrm{~min}$ and centrifuged at $14,000 \mathrm{x} \mathrm{g}$ for $15 \mathrm{~min}$ at $4^{\circ} \mathrm{C}$ to separate the supernatant from cellular debris. Total protein was measured using a Qubit Protein assay kit (Thermo Fisher 
Table I. The human breast cancer cell lines and normal breast cells used in the present study.

\begin{tabular}{lll}
\hline Cell line & \multicolumn{1}{c}{ Histology } & \multicolumn{1}{c}{ Subtype } \\
\hline T-47D & Ductal carcinoma & Luminal \\
ZR-75-1 & Ductal carcinoma & Luminal \\
MCF-7 & Ductal carcinoma & Luminal \\
AU565 & Adenocarcinoma & HER2/neu positive \\
SK-BR-3 & Adenocarcinoma & HER2/neu positive \\
HCC1599 & Ductal carcinoma & TNBC \\
HCC1143 & Ductal carcinoma & TNBC \\
HCC1937 & Primary ductal & TNBC \\
& carcinoma & \\
MDA-MB-231 & Adenocarcinoma & TNBC \\
BT-20 & Epithelial carcinoma & TNBC \\
MDA-MB-468 & Adenocarcinoma & TNBC \\
184A1 & Human mammary & \\
& epithelial cells & \\
\hline
\end{tabular}

The resource distributor of cells was the American Type Culture Collection (ATCC). TNBC, triple-negative breast cancer.

Table II. Characteristics of breast cancer tissues used for RT-qPCR.

\begin{tabular}{lc}
\hline Characteristics & No. of patients \\
\hline Sex & 0 \\
Male & 10 \\
Female & \\
Age (years) & 9 \\
$<65$ & 1 \\
$\geq 65$ & \\
Stage & \\
I & 0 \\
II & 7 \\
III & 3 \\
Histology & \\
Papillotubular carcinoma & 2 \\
Scirrhous carcinoma & 3 \\
Solid tubular carcinoma & 5 \\
\hline
\end{tabular}

Scientific, Inc.). The proteins were then mixed with sodium dodecyl sulfate sample buffer, boiled at $100^{\circ} \mathrm{C}$ for $5 \mathrm{~min}$, and incubated at room temperature for $5 \mathrm{~min}$. Following electrophoresis on 7.5 or $12 \%$ Mini-Protean ${ }^{\circledR}$ TGX gels (Bio-Rad Laboratories, Inc.), the proteins were transferred onto Trans-Blot ${ }^{\circledR}$ Turbo $0.2-\mu \mathrm{m}$ polyvinylidene difluoride membranes (Bio-Rad Laboratories, Inc.). The membranes were blocked with Block Ace ${ }^{\circledR}$ (Dainippon Pharmaceutical) for $1 \mathrm{~h}$, following which they were incubated overnight with rabbit polyclonal anti-KIF20A antibody (1:500, cat. no. A300-879A; Bethyl Laboratories) at $4^{\circ} \mathrm{C}$. Immunoreactive proteins were incubated with anti-rabbit horseradish peroxidase (HRP)-conjugated secondary antibodies (1:5,000, GE Healthcare Life Sciences) for $1 \mathrm{~h}$ at room temperature. Protein bands were visualized by chemiluminescence western blotting detection reagents using an ImageQuant LAS 4000 mini (GE Healthcare Life Sciences).

Immunocytochemistry. Cultured cells were washed twice with Dulbecco's phosphate-buffered saline [PBS(-); cat. no. C14190500; Life Technologies; Thermo Fisher Scientific, Inc.] and fixed in $4 \%$ paraformaldehyde solution for $15 \mathrm{~min}$ at room temperature. Cells were rendered permeable using PBS(-) containing $0.2 \%$ Triton $\mathrm{X}-100$ for $2 \mathrm{~min}$ at room temperature. Thereafter, the cells were covered with blocking solution containing 3\% bovine serum albumin in PBS(-) for $30 \mathrm{~min}$ to block non-specific binding prior to the primary antibody reaction. Subsequently, the cells were incubated with the rabbit polyclonal anti-KIF20A antibody (1:200, cat. no. A300-879A; Bethyl Laboratories) in a wet chamber for $1 \mathrm{~h}$ at room temperature. The immune complexes were stained with Alexa Fluor ${ }^{\circledR}$ 488-conjugated goat anti-rabbit IgG secondary antibody (1:1,000, cat. no. A11008; Life Technologies; Thermo Fisher Scientific, Inc.) in a wet chamber for $1 \mathrm{~h}$ at room temperature. Mounting medium with DAPI (Vector Laboratories, Inc.) was used to coverslip the slides. KIF20A staining was visualized under a microscope (BZ-X710, Keyence Corp.).

Immunohistochemistry and tissue microarray analysis. Tumor tissue microarrays were constructed according to previously published procedures (39). Formalin-fixed breast cancers were obtained at the Kanagawa Cancer Center. The tissue areas selected for sampling were determined by visual alignment with the corresponding hematoxylin and eosin-stained sections on slides. Three, four or five tissue cores (diameter, $0.6 \mathrm{~mm}$; height, 3-4 mm) obtained from donor tumor blocks were placed into recipient paraffin blocks using a tissue microarrayer (Beecher Instruments). The tissue microarray slides were de-paraffinized and heat-induced antigen retrieval was conducted in an autoclave using Target Retrieval Solution ( $\mathrm{pH}$ 9). Endogenous peroxidase was blocked (Dako; Agilent Technologies, Inc.) and the anti-KIF20A antibody (1:100, cat. no. A300-879A; Bethyl Laboratories) was added. The sections were incubated at room temperature for $1 \mathrm{~h}$ prior to incubation with EnVision+System-HRP labeled polymer anti-rabbit secondary antibody (cat. no. K4003; Dako; Agilent Technologies, Inc.) for $30 \mathrm{~min}$ at room temperature. 3,3'-Diaminobenzidine (DAB) chromogen and DAB substrate buffer were added, and the specimens were counterstained with hematoxylin and eosin for $1 \mathrm{~min}$ room temperature. The staining intensity within each tumor tissue core was mostly homogenous, facilitating the semi-quantitative evaluation of the KIF20A staining intensity by three independent investigators. KIF20A expression patterns in the tissue arrays were classified ranging from absent/weak to strong. Cases were defined as strongly positive if all of the three reviewers independently classified them as such.

RNA interference assay. siRNA oligonucleotides (Sigma-Aldrich; Merck KGaA) were used to evaluate the biological functions of KIF20A in breast cancer cells. The 
Table III. Association between KIF20A-positivity in breast cancer tissues and patient characteristics.

\begin{tabular}{|c|c|c|c|c|c|}
\hline \multirow[b]{2}{*}{ Characteristics } & \multirow[b]{2}{*}{$\begin{array}{l}\text { Total no. of patients } \\
\qquad(\mathrm{n}=257)\end{array}$} & \multicolumn{3}{|c|}{ KIF20A expression } & \multirow[b]{2}{*}{$\begin{array}{c}\text { P-value positive } \\
\text { vs. absent expression }\end{array}$} \\
\hline & & $\begin{array}{l}\text { Strong positive } \\
\quad(\mathrm{n}=106)\end{array}$ & $\begin{array}{l}\text { Weak positive } \\
\qquad(\mathrm{n}=89)\end{array}$ & $\begin{array}{l}\text { Absent } \\
(\mathrm{n}=62)\end{array}$ & \\
\hline Age (years) & & & & & 0.8639 \\
\hline$<65$ & 193 & 85 & 62 & 46 & \\
\hline$\geq 65$ & 64 & 21 & 27 & 16 & \\
\hline \multicolumn{6}{|l|}{ ER status } \\
\hline Negative & 71 & 35 & 30 & 6 & $0.0002^{\mathrm{a}}$ \\
\hline Positive & 186 & 71 & 59 & 56 & \\
\hline \multicolumn{6}{|l|}{ PgR status } \\
\hline Negative & 98 & 44 & 38 & 16 & $0.0245^{\mathrm{a}}$ \\
\hline Positive & 159 & 62 & 51 & 46 & \\
\hline \multicolumn{6}{|l|}{ HER2/neu status } \\
\hline Negative & 212 & 84 & 71 & 57 & $0.0333^{\mathrm{a}}$ \\
\hline Positive & 45 & 22 & 18 & 5 & \\
\hline \multicolumn{6}{|l|}{$\begin{array}{l}\text { Triple-negative breast } \\
\text { cancer (TNBC) }\end{array}$} \\
\hline TNBC & 39 & 20 & 16 & 3 & \\
\hline Others & 218 & 86 & 73 & 59 & \\
\hline \multicolumn{6}{|l|}{ Histology } \\
\hline Invasive lobular carcinoma & 6 & 2 & 1 & 3 & \\
\hline Scirrhous carcinoma & 87 & 30 & 30 & 27 & $0.0348^{\mathrm{a}, \mathrm{b}}$ \\
\hline Papillotubular carcinoma & 65 & 28 & 26 & 11 & \\
\hline Solid tubular carcinoma & 64 & 32 & 24 & 8 & \\
\hline Invasive ductal carcinoma & 5 & 1 & 2 & 2 & \\
\hline Mucinous carcinoma & 10 & 6 & 1 & 3 & \\
\hline DCIS & 13 & 4 & 2 & 7 & \\
\hline Apocrine carcinoma & 3 & 1 & 2 & 0 & \\
\hline Others & 4 & 2 & 1 & 1 & \\
\hline \multicolumn{6}{|l|}{ pT factor } \\
\hline $\mathrm{T} 1$ & 91 & 25 & 34 & 32 & $0.0035^{\mathrm{a}}$ \\
\hline $\mathrm{T} 2-\mathrm{T} 3$ & 166 & 81 & 55 & 30 & \\
\hline \multicolumn{6}{|l|}{$\mathrm{pN}$ factor } \\
\hline NO & 148 & 50 & 56 & 42 & 0.0767 \\
\hline $\mathrm{N} 1-\mathrm{N} 2$ & 109 & 56 & 33 & 20 & \\
\hline
\end{tabular}

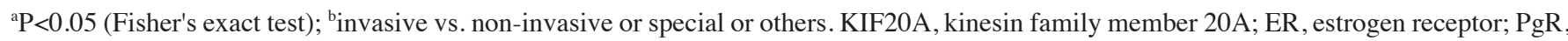
progesterone receptor; HER2, human epidermal growth factor receptor 2; DCIS, ductal carcinoma in situ.

sequences targeting each gene were as follows: Control 1 si-Luciferase (LUC), 5'-CGUACGCGGAAUACUUCGATT-3'; Control 2 si-EGFP, 5'-GAAGCAGCACGACUUCUUCTT-3'; KIF20A-suppressing siRNA (si-KIF20A) \#1, 5'-GUUCUC AGCCAUUGCUAGCTT-3'; and si-KIF2OA \#2, 5'-CCCUUA UGCCCGGAUCCUATT-3'. Breast cancer cell lines were incubated with medium containing siRNAs $(50 \mu \mathrm{M})$ and Lipofectamine 2000 reagent (Thermo Fisher Scientific, Inc.), for $4 \mathrm{~h}$ at $37^{\circ} \mathrm{C}$ in a $\mathrm{CO}_{2}$ incubator. Following incubation, the transfection mixture was removed and replace with $1 \mathrm{X}$ normal growth medium
Cell viability assay. The transfected cells were seeded on a 6 -well plate at a density of $4 \times 10^{4}$ cells/well. Cell viability was evaluated 7 days following transfection using a Cell Counting Kit-8 (Dojindo Laboratories, Inc.).

Colony formation assay. The colony formation assay was performed using Giemsa solution (WAKO) staining. Images were captured by MP990-PIXUS (Canon). The transfected cells were seeded on a $10 \mathrm{~cm}$ dish at a density of $2 \times 10^{5}$ cells/well. Following incubation for 7 days, the treated cells were fixed with $100 \%$ methanol for $30 \mathrm{~min}$ at room temperature and 
A

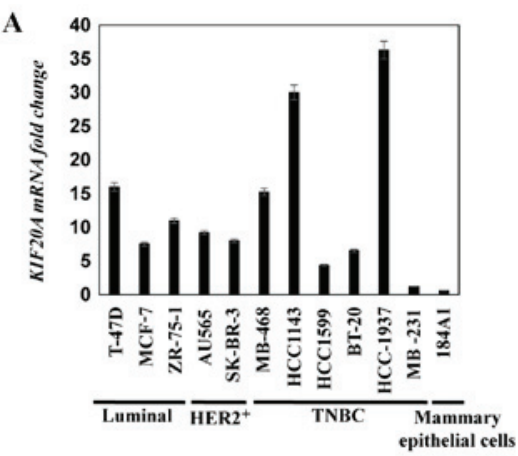

C
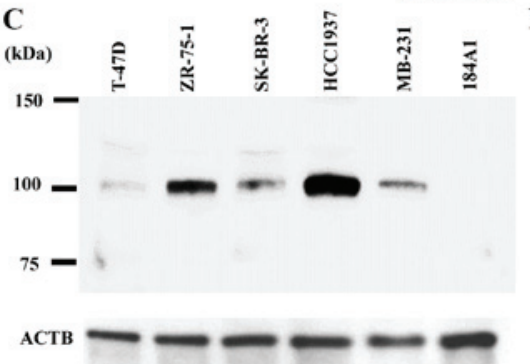
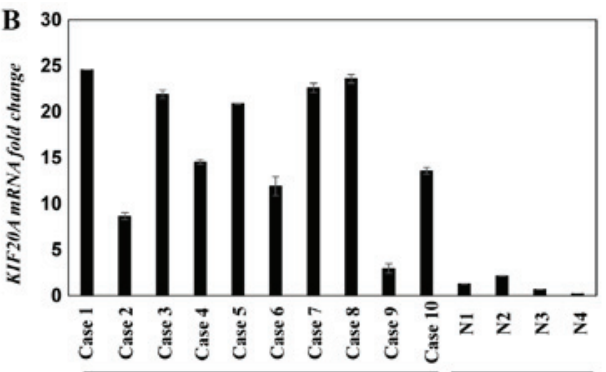

D $\quad$ ZR-75-1
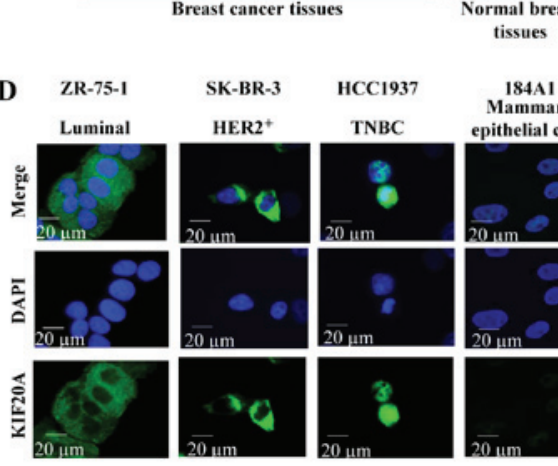

SK-BR-3

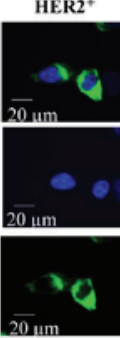

HCC1937

tissues

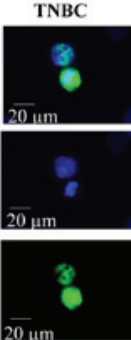

$184 \mathrm{Al}$
Mammary

Mammary
epithelial cells

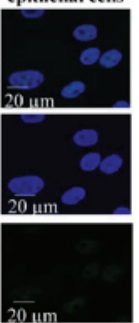

Figure 1. KIF20A expression in breast cancer cells and tissues. (A and B) KIF20A mRNA expression detected using RT-qPCR in breast cancer cell lines (n=11), a normal breast epithelial cell line, human breast cancer tissues $(n=10)$, and in adjacent human breast tissues $(n=4)$. (C) KIF20A protein expression detected by western blot analysis in breast cancer cell lines. (D) Subcellular localization of endogenous KIF20A protein in breast cancer cells and breast epithelial cells. Cells were stained with a rabbit polyclonal anti-KIF20A antibody (green) and DAPI (blue). Staining for KIF20A was primarily observed in the cytoplasm and nucleus in positive breast cancer cells, whereas no staining was observed in 184A1 cells. KIF20A, kinesin family member 20A; HER2, human epidermal growth factor receptor 2; TNBC, triple-negative breast cancer.

stained with Giemsa solution (Wako Pure Chemical Industries, Ltd.) for $20 \mathrm{~min}$ at room temperature.

KIF20A inhibitor assay. First, dose-response experiments with paprotrain using the ZR-75-1 cells at concentrations of 50,100 or $200 \mu \mathrm{M}$ were performed; $200 \mu \mathrm{M}$ of paprotrain (Merck KGaA) treatment significantly inhibited the cell growth and was thus adopted to compare the effect of paprotrain on various cell lines under the same conditions. The ZR-75-1, SK-BR-3 and HCC1937 cells were treated with $200 \mu \mathrm{M}$ of paprotrain for $24 \mathrm{~h}$ (Merck KGaA) to examine the growth suppressive effects of a selective cell-permeable KIF20A inhibitor in breast cancer cells using MTT assay, flow cytometry and live-cell imaging.

Flow cytometric analysis. Flow cytometric analysis was performed using the CycletestPlus DNA Reagent kit (cat. no. 340242; BD Biosciences) and the FACSVerse system (BD Biosciences). The breast cancer cells lines were transfected with siRNA oligonucleotides or treated with $200 \mu \mathrm{M}$ of paprotrain for $24 \mathrm{~h}$. Following treatment, $1.0 \times 10^{6}$ cells were harvested for DNA ploidy staining. The samples were filtered through a 70- $\mu \mathrm{m}$ nylon mesh and stored on ice in the dark. The cell cycle was analyzed within $3 \mathrm{~h}$ using the FACSVerse flow cytometer. The DNA content was analyzed in 20,000 ungated cells.

Live-cell imaging. Live-cell imaging was performed using the Evos FL Auto Imaging System (Thermo Fisher Scientific, Inc.) to monitor cytokinetics. Breast cancer cells were seeded into 35-mm glass dishes in medium containing 10\% FBS. Images were captured every $15 \mathrm{~min}$ following si-KIF20A transfec- tion or paprotrain treatment using a fully-automated imaging system of Evos FL Auto Imaging System.

Matrigel invasion assay. The ZR-75-1, SK-BR-3 and HCC1937 cells transfected either with siRNA against KIF20A or with si-control $(L U C)$ were grown to near confluence in culture medium containing 10\% FBS. The cells were harvested by trypsinization, washed in medium without the addition of serum or protease inhibitor, and suspended in medium at a concentration of $2 \times 10^{5}$ per milliliter. Before preparing the cell suspension, the dried layer of Matrigel matrix (BD Biosciences) was rehydrated with medium for $2 \mathrm{~h}$ at room temperature. Medium (0.75 ml) containing $10 \%$ FBS was added to each lower chamber in 24-well Matrigel invasion chambers, and $0.5 \mathrm{ml}\left(1 \times 10^{5}\right.$ cells $)$ of cell suspension in growth medium with $0.1 \%$ FBS was added to each insert of the upper chamber. The plates of inserts were incubated for $22 \mathrm{~h}$ at $37^{\circ} \mathrm{C}$, in which condition, no growth-promoting effect by si-KIF20A expression was also confirmed by MTT assay. The chambers were processed, and cells invading through the Matrigel were fixed and stained with Giemsa for $1 \mathrm{~h}$ at room temperature as directed by the supplier (BD Biosciences).

Statistical analysis. Statistical analyses were conducted using StatView (JMP) and SPSS 25 software (IBM, Inc.). The significance test analyzing the difference between 2 groups of cell-based assays was performed using the Student's t-test. One-way ANOVA followed by Tukey's post hoc test were performed to compare the means of each group with the means of every other group when performing multiple comparisons. Fisher's exact test was used to assess the association between KIF20A expression and the clinicopathological variables of the 

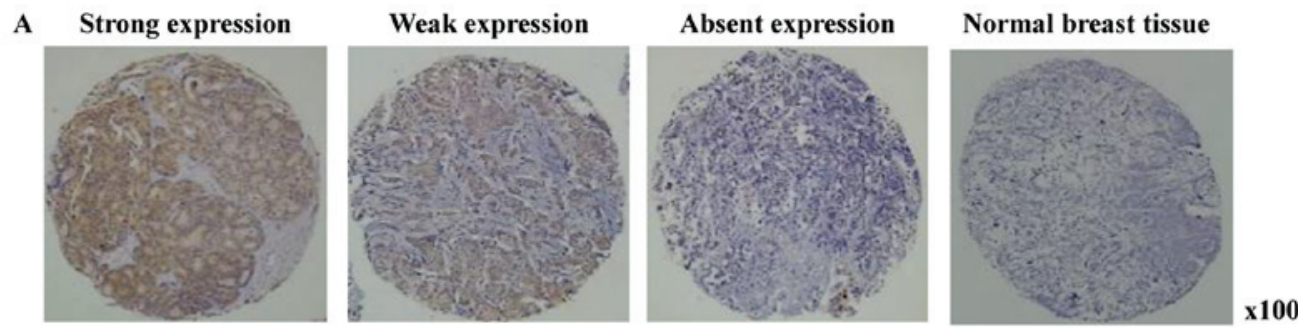

B

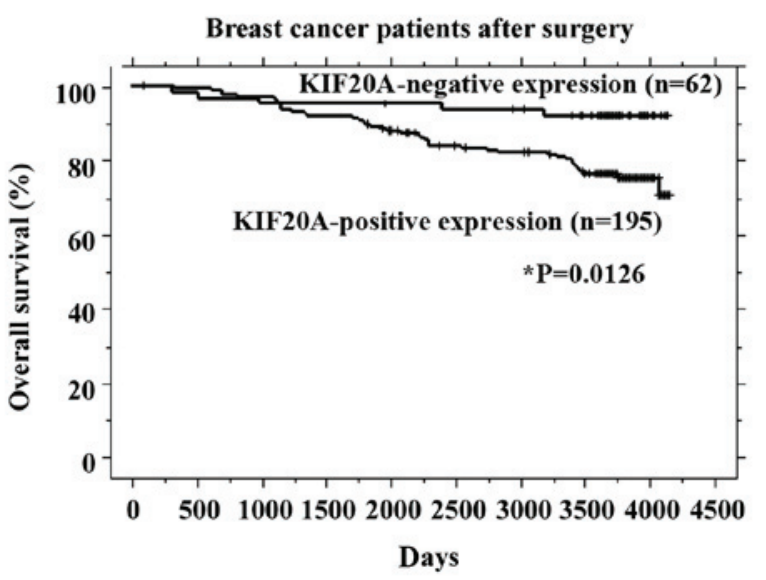

Figure 2. KIF20A expression is associated with the poor prognosis of patients with breast cancer. (A) Immunohistochemical staining pattern of KIF20A protein in representative breast cancer tissues for strong, weak and absent KIF20A expression and a normal breast epithelia tissue (original magnification, $\mathrm{x} 100)$. (B) Kaplan-Meier analysis of survival of patients $(\mathrm{n}=257)$ with breast cancer according to KIF20A expression ( $\mathrm{P}=0.0126, \log -\mathrm{rank}$ test). KIF20A, kinesin family member $20 \mathrm{~A}$.

patients, including age, histology type, ER status, PgR status, HER2 status and pathological T (pT) and $\mathrm{N}(\mathrm{pN})$ factors. An overall survival (OS) curve was calculated from the date of surgery to the time of breast cancer-related mortality or to the final follow-up observation. Kaplan-Meier curves were calculated for each relevant variable and for KIF20A expression. Differences in survival duration among patient subgroups were analyzed using the log-rank test. Univariate and multivariate analyses were conducted using the Cox proportional hazard regression model to determine associations between clinicopathological variables and cancer-related mortality. Individual associations were first analyzed between death and possible prognostic factors, including age, ER status, PgR status, HER2 status, $\mathrm{pT}$ classification and $\mathrm{pN}$ classification. Subsequently, a multivariate analysis was conducted using backward (stepwise) procedures that forced KIF20A expression into the model, along with each variable that satisfied an entry level of $\mathrm{P}<0.05$. As factors were continually added to the model, independent factors did not exceed an exit level of $\mathrm{P}<0.05$.

Database analysis. The association between KIF20A gene expression and the survival of breast cancer patients was evaluated by PrognoScan (http://www.prognoscan.org/). Signaling pathways related to KIF20A were screened by ONCOMINE database (https://www.oncomine.org/resource/login.html) and the GSEA database (software.broadinstitute.org/gsea/msigdb/).

\section{Results}

KIF20A expression in breast cancer cell lines and tissues. RT-qPCR revealed higher KIF2OA mRNA expression levels in the majority of the 11 breast cancer cell lines compared with the 184A1 breast epithelial cells (Fig. 1A). Furthermore, KIF20A was expressed in the majority of the clinical breast cancer tissues, whereas it was barely detectable in the adjacent breast tissues (Fig. 1B). Western blot analysis revealed that KIF20A protein was expressed in the majority of the breast cancer cells, whereas it was barely detectable in normal breast cells (Fig. 1C). Immunocytochemical analysis revealed that KIF20A protein was detected in the cytoplasm and/or nucleus of ZR-75-1 (Luminal A), SK-BR-3 (HER2/neu-positive) and HCC1937 (TNBC with BRCA1 mutation) cell lines (Fig. 1D). KIF20A was localized in the cytoplasm and the nucleus of breast cancer cells.

KIF20A expression is associated with the poor prognosis of patients with breast cancer. Immunohistochemistry revealed that KIF20A was expressed in 195 of the 257 (75.9\%) breast cancer cases investigated. A strong expression was present in 106 cases (41.3\%), a weak expression was present in 89 cases (34.6\%), and the expression was absent in 62 cases (24.1\%) (Fig. 2A and Table III). On classification based on the breast cancer subtype, KIF20A was expressed in 130 of 186 (69.9\%) hormone receptor-positive breast cancers, in 40 of 45 (88.9\%) HER2-positive breast cancers, and in 36 of 39 (92\%) TNBCs. KIF20A was more frequently expressed in HER2-positive breast cancer and TNBC compared to the other types.

Furthermore, the associations between KIF20A protein expression and the patient clinicopathological parameters were assessed. The ER status factor (higher expression in ER-negative; $P=0.0002$, Fisher's exact test), $P$ gR status factor (higher expression in PgR-negative; $\mathrm{P}=0.0245$, Fisher's exact 
Table IV. Cox proportional hazards model analysis of prognostic factors in patients with breast cancer.

\begin{tabular}{|c|c|c|c|c|}
\hline Variables & Hazards ratio & $95 \% \mathrm{CI}$ & Unfavorable/favorable & P-value \\
\hline \multicolumn{5}{|l|}{ Univariate analysis } \\
\hline KIF20A expression & 3.152 & $1.253-7.929$ & Positive/absent & $0.0147^{\mathrm{a}}$ \\
\hline Age (years) & 1.045 & $0.558-1.958$ & $\geq 65 /<65$ & 0.8908 \\
\hline ER status & 1.687 & $0.959-2.967$ & Negative/positive & 0.0695 \\
\hline PgR status & 1.65 & $0.957-2.845$ & Negative/positive & 0.0713 \\
\hline HER2/neu status & 1.142 & $0.573-2.278$ & Positive/negative & 0.7051 \\
\hline T-factor & 2.173 & $1.117-4.230$ & $\mathrm{~T} 2-3 / \mathrm{T} 1$ & $0.0223^{\mathrm{a}}$ \\
\hline $\mathrm{N}$-factor & 3.744 & $2.054-6.823$ & N1-2/N0 & $<0.0001^{\mathrm{a}}$ \\
\hline \multicolumn{5}{|l|}{ Multivariate analysis } \\
\hline KIF20A expression & 2.698 & $1.068-6.813$ & Positive/absent & $0.0357^{\mathrm{a}}$ \\
\hline T-factor & 1.46 & $0.739-2.886$ & $\mathrm{~T} 2-3 / \mathrm{T} 1$ & 0.2762 \\
\hline N-factor & 3.311 & $1.795-6.108$ & N1-2/N0 & $0.0001^{\mathrm{a}}$ \\
\hline
\end{tabular}

${ }^{a} \mathrm{P}<0.05$. CI, confidence interval; KIF20A, kinesin family member 20A; ER, estrogen receptor; PgR, progesterone receptor; HER2, human epidermal growth factor receptor 2 .

test), HER2 status factor (higher expression in HER2-positive; $\mathrm{P}=0.0333$, Fisher's exact test) and pT factor (higher expression in T2-3; P=0.0035, Fisher's exact test) were significantly associated with KIF20A expression (Table III). Kaplan-Meier analysis revealed that a positive KIF20A expression was significantly associated with a shorter OS compared with no KIF20A expression ( $\mathrm{P}=0.0126$, log-rank test, Fig. 2B). Univariate analysis was also performed to investigate the association of patient prognosis with factors, including KIF20A expression status (positive vs. negative), age ( $\geq 65$ vs. $<65$ years), ER status (negative vs. positive), PgR status (negative vs. positive), HER2 status (positive vs. negative), pT classification (T2-3 vs. T1) and pN classification (N1-2 vs. N0). Univariate analysis revealed that a positive KIF20A expression $(\mathrm{P}=0.0147)$, an advanced $\mathrm{pT}$ stage $(\mathrm{P}=0.0223)$ and an advanced $\mathrm{pN}$ stage $(\mathrm{P}<0.0001)$ were significantly associated with a worse prognosis. Furthermore, multivariate analysis revealed that a positive KIF20A expression and an advanced $\mathrm{pN}$ stage were independent prognostic factors ( $\mathrm{P}=0.0357$ and $\mathrm{P}=0.0001$, respectively, Table IV).

To validate the potential of KIF20A as a prognostic biomarker, the prognostic value of KIF20A gene expression was also investigated using the PrognoScan database. KIF20A expression was significantly associated with the poor prognosis of breast cancer patients (dataset no. GSE1456-GPL96; $\mathrm{P}=0.001501)$. The data independently support the immunohistochemical data of the present study.

si-KIF20A inhibits breast cancer cell growth. To elucidate whether KIF20A upregulation plays a significant role in breast cancer cell growth, ZR-75-1 (Luminal A), SK-BR-3 (HER2/neu-positive) and HCC1937 (TNBC with BRCA1 mutation) cell lines were transfected with si-KIF20As to suppress KIF20A expression. Western blot analysis revealed that si-KIF20A decreased the KIF20A protein levels in the cancer cells compared with the control siRNA (Fig. 3A). In addition, si-KIF20A significantly inhibited breast cancer cell viability (Fig. 3B). Moreover, colony formation assays revealed that si-KIF20A decreased the number of breast cancer cells (Fig. 3C).

si-KIF20A inhibits the cell cycle progression of breast cancer cells. To further investigate the mechanisms of tumor growth regulated by KIF20A, flow cytometric analysis of the cell cycle was performed following siRNA transfection. Flow cytometric analysis revealed that compared with the control siRNA, si-KIF20A significantly increased the population of cells in the $\mathrm{G} 2 / \mathrm{M}$ phase at $72 \mathrm{~h}$ post-transfection (ZR-75-1 cells, $\mathrm{P}=0.0019$; SK-BR-3 cells, $\mathrm{P}<0.0001$; and HCC1937 cells, $\mathrm{P}<0.0001$; population of cells at each cell cycle is shown as a percentage and in flow cytometric images in Fig. 4A and B). Morphological changes were monitored using live-cell imaging of the ZR-75-1, SK-BR-3 and HCC1937 cells transfected with si-KIF20A (Fig. 4C and D). Time-lapse imaging detected regular cell division in cells transfected with control siRNA, whereas very few cell divisions, as well as subsequent death were observed in all cells transfected with si-KIF20A.

Paprotrain inhibits breast cancer cell growth by blocking the kinesin motor ATPase activity of KIF20A. The breast cancer cells, ZR-75-1 (Luminal A), SK-BR-3 (HER2/neu-positive) and HCC1937 (TNBC with BRCAl mutation) were incubated in medium with or without paprotrain to assess two lines of research: The first was to observe the functional role of the kinesin motor ATPase activity of KIF20A via pharmacological inhibition and the second was to assess the potential of selective KIF20A inhibitor for clinical use. MTT assay revealed that incubation with paprotrain for $24 \mathrm{~h}$ significantly decreased breast cancer cell viability (Fig. 5A). Furthermore, flow cytometric analysis performed $24 \mathrm{~h}$ following paprotrain treatment revealed that the number of cells in the G2/M phase was significantly higher than the number of cells without paprotrain treatment (population of cells in each cell cycle is shown as a percentage and in flow cytometric images in Fig. 5B and C). Live-cell imaging revealed that the cancer 

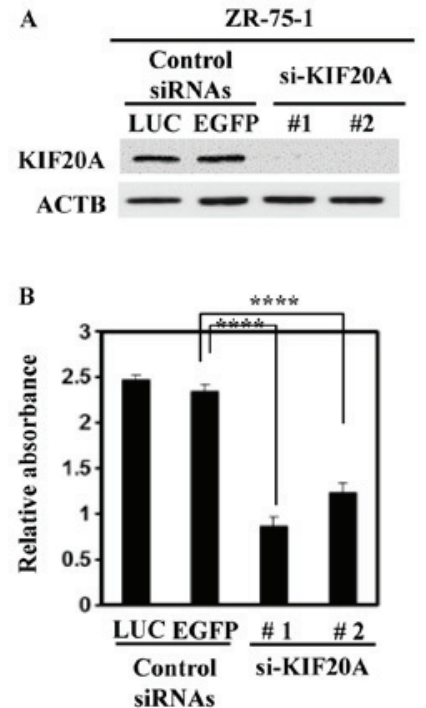

$\mathrm{C}$

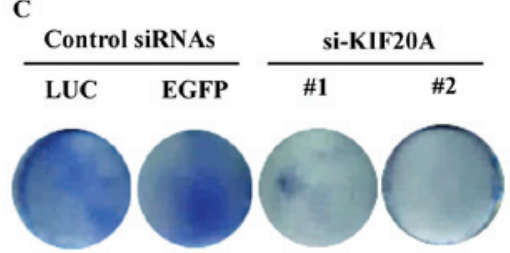

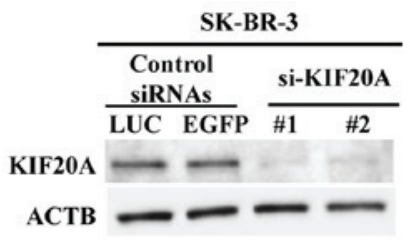
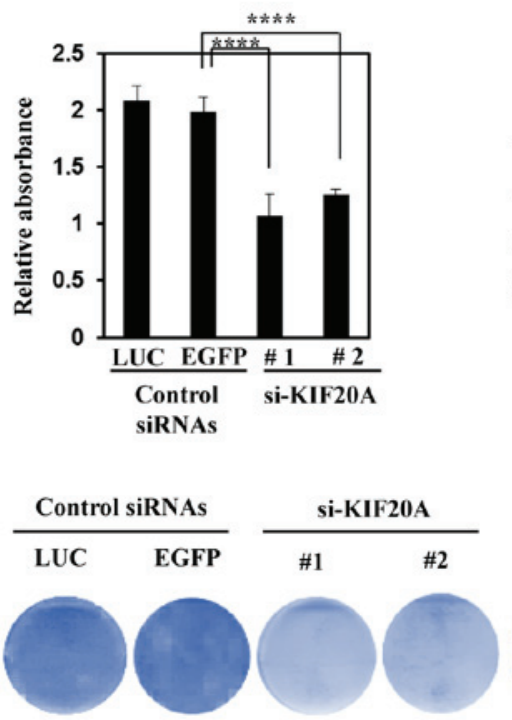
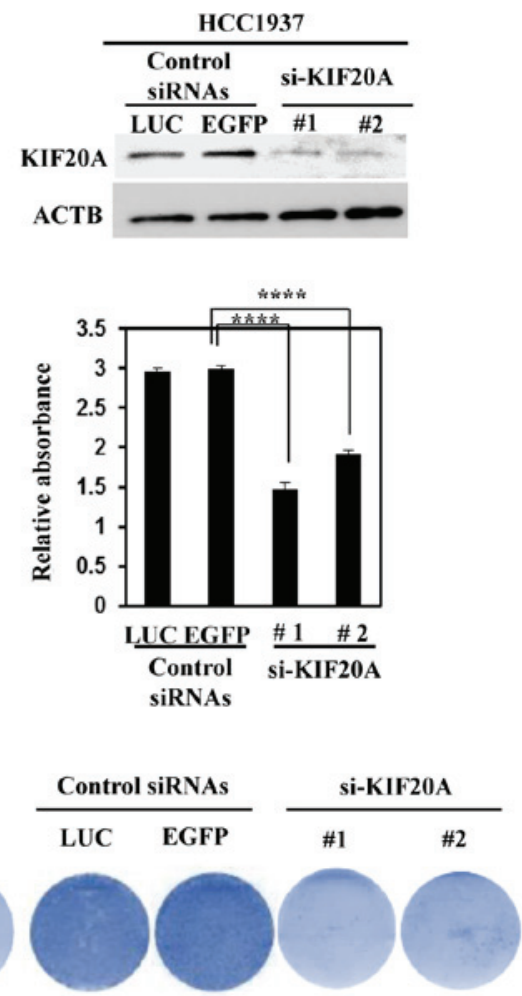

Figure 3. si-KIF20A inhibits breast cancer cell growth. (A) Western blot analysis demonstrated the suppression of KIF20A protein expression in breast cancer cells transfected with si-KIF20A compared with control siRNA (si-controls). (B) MTT assay for cells transfected with si-KIF20A or si-controls. (C) Colony formation assay for cells transfected with si-KIF20A or si-controls. ${ }^{* * * *} \mathrm{P}<0.0001$ vs. si-control group. KIF20A, kinesin family member $20 \mathrm{~A}$.
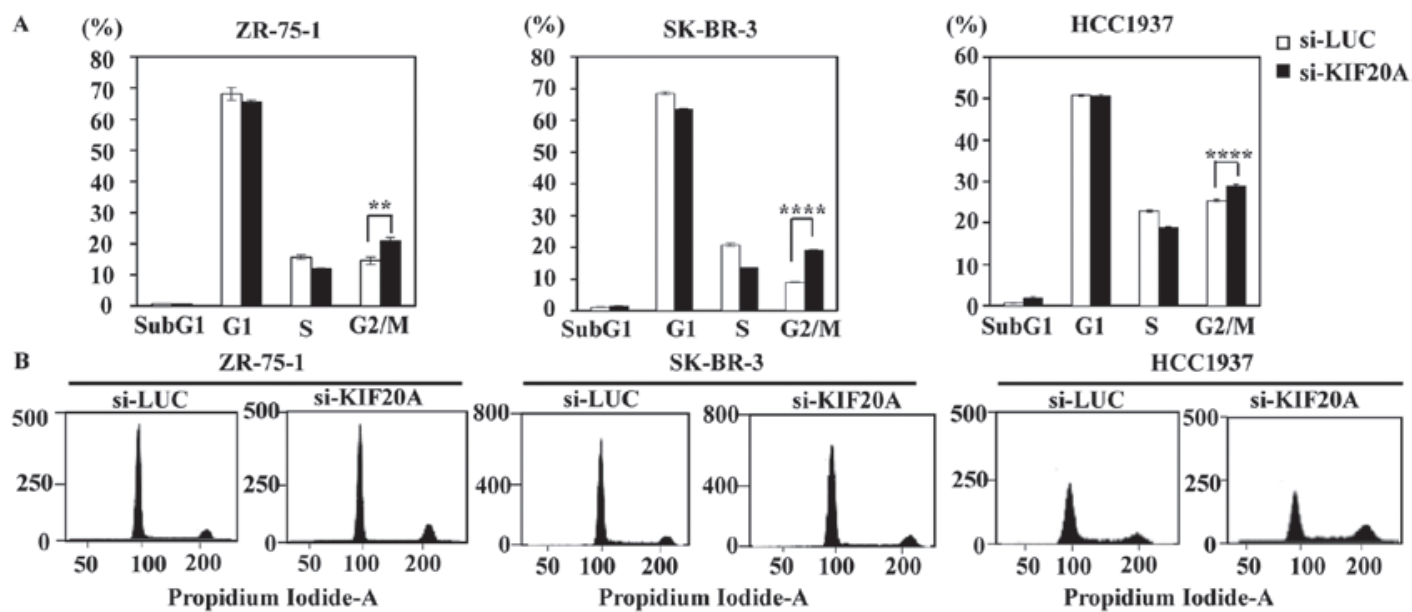

C HCC1937
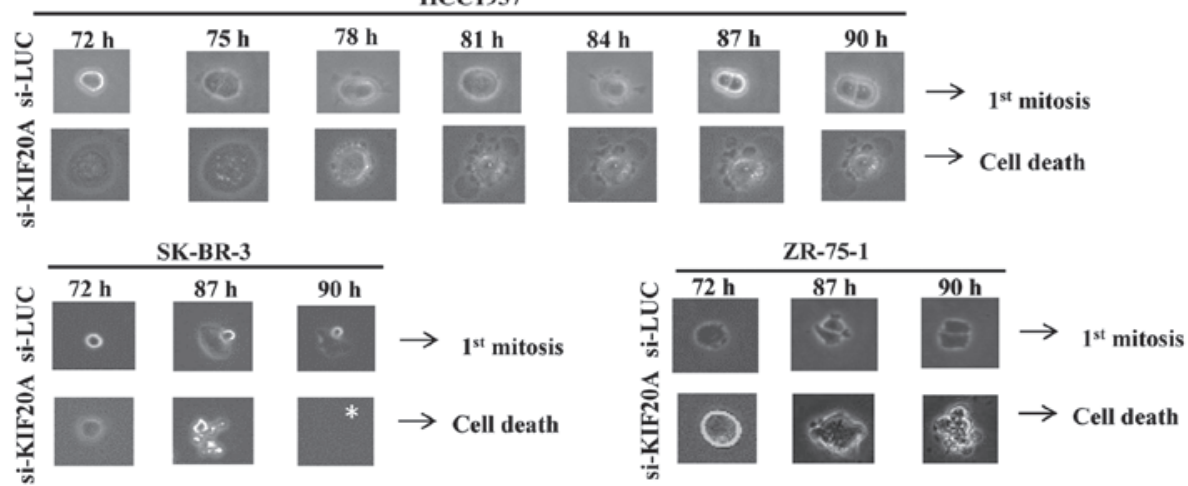

Figure 4. si-KIF20A inhibits cell cycle progression and the induction of cell death in breast cancer cells. (A and B) Flow cytometry indicates the percentage of cells at each cell cycle phase in three subtypes of breast cancer cells following si-KIF20A transfection. (C) Time-lapse imaging of HCC1937 cells transfected with si-KIF20A. (D) Time lapse imaging of SK-BR-3 cells and ZR-75-1 cells transfected with si-KIF20A. The asterisk in the image in part D (") indicates that the dead cell peeled and disappeared from microscopic field of view. ${ }^{* *} \mathrm{P}<0.01,{ }^{* * * * *} \mathrm{P}<0.0001$ vs. si-control group. KIF20A, kinesin family member $20 \mathrm{~A}$. 

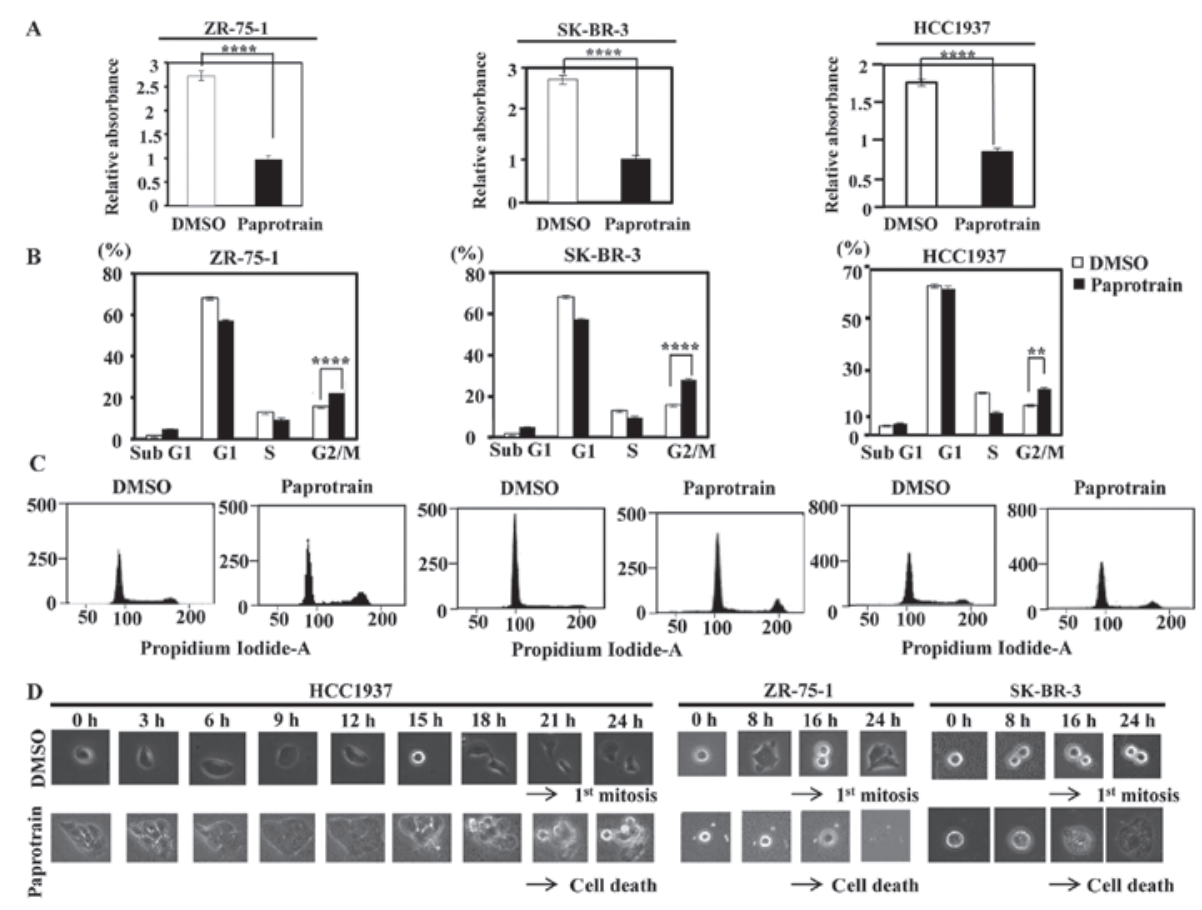

Figure 5. Paprotrain inhibits breast cancer cell growth. (A) MTT assay for cells treated with paprotrain. (B and C) Flow cytometry indicates the percentage of cells at each cell cycle phase in breast cancer cells following paprotrain treatment. (D) Time lapse imaging of HCC1937 cells, SK-BR-3 cells, and ZR-75-1 cells treated with paprotrain. ${ }^{* *} \mathrm{P}<0.01,{ }^{* * * *} \mathrm{P}<0.0001$ vs. DMSO control group. KIF20A, kinesin family member $20 \mathrm{~A}$.
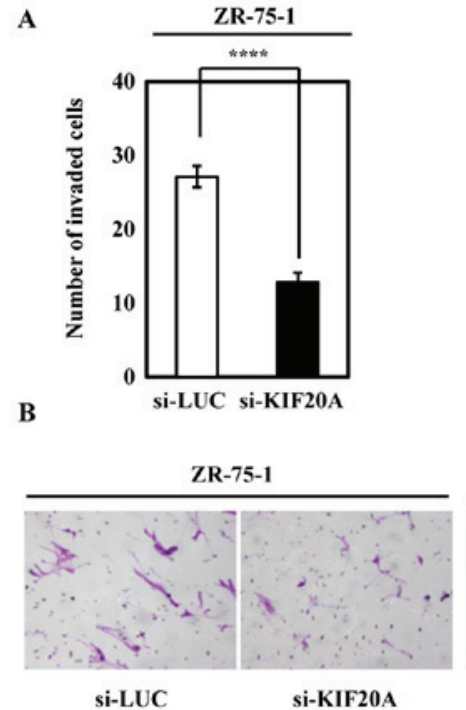
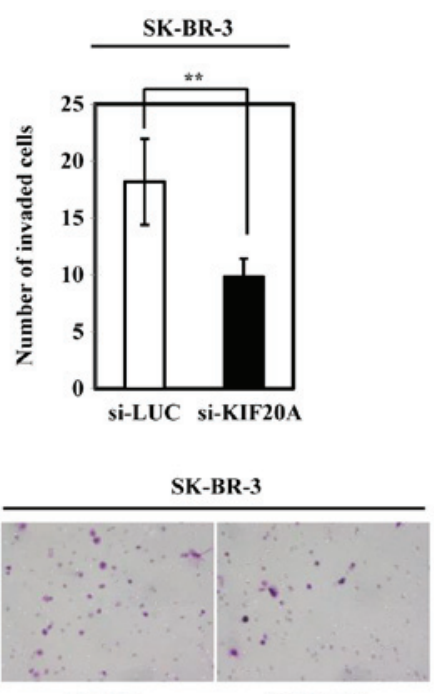

si-LUC

si-KIF20A
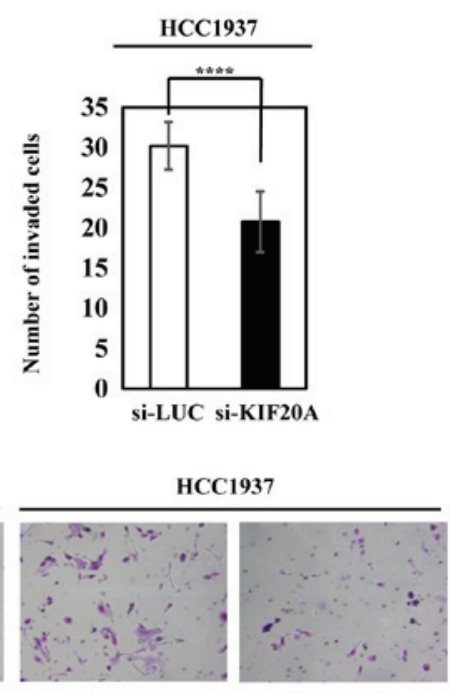

si-LUC

si-KIF20A

Figure 6. si-KIF20A inhibits the invasive ability of breast cancer cells. (A and B) Assays showing the invasive nature of ZR-75-1, SK-BR-3 and HCC1937 cells in Matrigel matrix following transfection with siRNA against KIF20A. The relative number of cells (A) migrating through the Matrigel-coated filters and (B) Giemsa staining. Assays were carried out thrice and in triplicate wells. ${ }^{* *} \mathrm{P}<0.01,{ }^{* * * * *} \mathrm{P}<0.0001$ vs. si-control group. KIF20A, kinesin family member $20 \mathrm{~A}$.

cells without paprotrain treatment divided regularly, whereas paprotrain treatment resulted in cell cycle arrest in the $\mathrm{G} 2 / \mathrm{M}$ phase and subsequent cell death (Fig. 5D).

si-KIF20A inhibits invasive phenotype of breast cancer cells. The possible role of KIF20A in cellular invasion was examined by Matrigel assays using the ZR-75-1, SK-BR-3 and HCC1937 cells. Transfection with si-KIF20A or control siRNA into either of the cells significantly inhibited their invasive activity (Fig. 6). The results also indicated that KIF20A contributed to the more malignant phenotype of breast cancer cells.
In silico analysis of KIF20A-related pathways. Since KIF20A expression in breast cancer appears to play a role in mitosis, as reported in other types of cells $(33,34)$, the co-expression and co-localization of KIF20A protein with Aurora kinase B and PLK1 was initially confirmed in mitotic breast cancer cells by western blot analysis, the ONCOMINE database and immunocytochemistry (data not shown). To further screen novel KIF20A-related pathways, the GSEA database was used and it was found that KIF20A expression was likely to be related to various pathways, including genes for cell cycle and cell invasion, as well as Aurora B and PLK1 signaling (data not 
shown). The information functionally supports the data of the cell cycle analysis in the present study and live-cell imaging, as well as cell invasion assay using siRNAs for KIF20A.

\section{Discussion}

The current understanding of the molecular mechanisms and basic signaling pathways in breast cancer pathogenesis has led to the development of certain novel molecular targeted therapies, such as therapeutic antibodies and small compounds. Molecular targeted agents are expected to exhibit good clinical effectiveness against cancer cells due to their specific anticancer mechanisms of action. However, no agent can completely regulate the disease for prolonged periods of time due to the genetic and biological heterogeneity of breast cancer cells, as well as their drug resistance. Therefore, the development of novel, cost-effective therapeutic agents and intensive therapies, as well as the identification of precision medicine biomarkers are required to overcome highly malignant breast tumors. Effective potential molecular targets for cancer should exhibit a restricted expression in normal adult tissues. This reduces the cytotoxic off-target effects of the therapy and is indicative of specific cancer biomarkers (40-42). In the present study, KIF20A was expressed in the majority of breast cancer cells and tissues, whereas it was seldom detected in normal breast epithelial tissue. With the exception of the testes, KIF2OA is expressed at minimal levels in normal tissues and organs (BioGPS database; http://biogps.org/\#goto=welcome), suggesting that it is an ideal diagnostic and therapeutic target. To investigate the mechanisms of KIF20A activation in breast cancer, comparative genome hybridization and the genome sequencing database for KIF20A (https://cancer.sanger. ac.uk/cosmic) were used. Missense mutations in KIF20A were detected in $0.29 \%$ of breast cancer tissues (4/1,397 cases); however, no KIF20A gene amplification or translocation were reported. According to cBioportal for Cancer Genomics (http://www.cbioportal.org/), among 10,967 cases of breast cancer, missense mutations, deletions, and genetic amplification of KIF20A were detected in only 106 cases $(0.9 \%)$. It has been demonstrated that KIF20A expression is regulated by glioma-associated oncogene 2 via the FOXM1-MMB complex in hepatocellular cells and pancreatic cancer (43). Another study reported that KIF2OA transcriptional activity was regulated by E2F/DP binding to the promoter region of KIF20A (44). Therefore, KIF20A overexpression may be involved in several epigenetic mechanisms.

In the present study, the original tissue microarray analysis revealed that KIF $20 \mathrm{~A}$ overexpression was significantly associated with the poor prognosis of patients with breast cancer. In addition, PrognoScan revealed a significant association between a high KIF2OA expression and a reduced OS of patients with breast cancer (dataset no. GSE1456-GPL96; $\mathrm{P}=0.001501$ ), thereby independently supporting the current data that KIF20A may be a prognostic biomarker for these patients.

The present study demonstrated the potential clinical application of KIF20A inhibition for breast cancer treatment by selectively inhibiting the ATPase activity of KIF20A and suppressing KIF20A expression using siRNAs. Breast cancer cells were treated with the KIF20A inhibitor, paprotrain, which reversibly blocks KIF20A function by being uncompetitive with ATP and noncompetitive with microtubules (45-47). Similar to si-KIF20A, paprotrain decreased the viability of the ZR-75-1 (Luminal A), SK-BR-3 (HER2/neu-positive) and HCC1937 (TNBC with BRCAl mutation) breast cancer cell lines via G2/M arrest and subsequent mitotic cell death as monitored by live-cell imaging. Targeting KIF20A with more selective and potent small molecule inhibitors may be an effective therapeutic strategy for a wide variety of breast cancers. The newly developed, potent KIF20A inhibitor, BKS0349, was recently reported to suppress KIF20A ATPase activity at levels 2-10-fold greater than paprotrain in various cancer cell lines and in a xenograft mouse model without noticeable variation $(48,49)$. Further preclinical studies investigating KIF20A inhibitors are crucial for the development of novel molecular targeted drugs that can be used to treat highly malignant breast cancers, such as TNBC. As the information obtained by gene expression and inhibition assays using small number of breast cancer cell lines is limited, further detailed cell line assays considering KIF20A expression levels and cell phenotypes that can be categorized by breast cancer subtypes, as well as genome-wide genetic aberrations detected using whole genome sequencing are eagerly warranted.

To examine a mechanistic insight of KIF20A expression in breast cancer, the co-expression and co-localization of KIF20A protein with Aurora kinase B and PLK1 in mitotic breast cancer cells was initially confirmed by western blot analysis, the ONCOMINE database and immunocytochemistry; this was consistent with the findings described in other type of cells $(33,34,44,45)$. To further identify novel KIF20A-related pathways, the GSEA database was screened and it was found that KIF20A expression was likely to be related to various pathways, including cell cycle and cell invasion, as well as Aurora B and PLK1 signaling pathways.

In conclusion, these findings suggest that KIF20A is a common oncoprotein in breast cancer. KIF20A plays an essential role in breast cancer proliferation and invasion, and is a candidate prognostic marker. Therefore, targeting KIF20A may be useful for the development of novel treatments, such as immunotherapies and molecular targeted therapies, which can exert potent biological effects on cancer with minimal adverse effects.

\section{Acknowledgements}

Not applicable.

\section{Funding}

Not applicable.

\section{Availability of data and materials}

All data generated or analyzed during this study are included in this published article.

\section{Authors' contributions}

MN, AT and YD were involved in the conception and design of the study. MN, AT, PMT and YD were involved 
in the development of the study methodology. TYo, TYa, YM and YD were involved in the acquisition of data (such as acquiring and managing patients and providing facilities). MN, AT, PMT, BT, MZ and YD were involved in the analysis and interpretation of data (e.g., statistical analysis, biostatistics and computational analysis). MN, AT and YD were involved in the writing, reviewing and/or revision of the manuscript. MN, AT, PMT and YD were involved in administrative, technical or material support (i.e., reporting or organizing data, constructing databases). YD supervised the study. All authors read and approved the final manuscript.

\section{Ethics approval and consent to participate}

The present study and the use of all clinical materials were approved by individual institutional ethics committees. The project to establish tumor tissue microarrays from archival formalin-fixed and paraffin-embedded surgically resected tissues and to use the tissue microarrays for later unspecified research works was approved by the Kanagawa Cancer Center Ethics Committee with the approval no. Rin-177, 27 (September, 2010). Written comprehensive informed consent was obtained from the patients for the use of their clinical information and for specimens remaining after clinically required examinations, such as archival formalin-fixed and paraffin-embedded specimens following diagnosis.

\section{Patient consent for publication}

Not applicable.

\section{Competing interests}

The authors declare that they have no competing interests.

\section{References}

1. Siegel RL, Miller KD and Jemal A: Cancer statistics, 2019. CA Cancer J Clin 69: 7-34, 2019.

2. Dai X, Xiang L, Li T and Bai Z: Cancer hallmarks, biomarkers and breast cancer molecular subtypes. J Cancer 7: 1281-1294, 2016.

3. Loi S, Haibe-Kains B, Desmedt C, Lallemand F, Tutt AM, Gillet C, Ellis P, Harris A, Bergh J, Foekens JA, et al: Definition of clinically distinct molecular subtypes in estrogen receptor-positive breast carcinomas through genomic grade. J Clin Oncol 25: 1239-1246, 2007.

4. Schroeder RL, Stevens CL and Sridhar J: Small molecule tyrosine kinase inhibitors of ErbB2/HER2/Neu in the treatment of aggressive breast cancer. Molecules 19: 15196-15212, 2014.

5. Hudis CA and Gianni L: Triple-negative breast cancer: An unmet medical need. Oncologist 16 (Suppl 1): 1-11, 2011.

6. Robson M, Im SA, Senkus E, Xu B, Domchek SM, Masuda N, Delaloge S, Li W, Tung N, Armstrong A, et al: Olaparib for metastatic breast cancer in patients with a germline BRCA mutation. N Engl J Med 377: 523-533, 2017.

7. Adams S, Schmid P, Rugo HS, Winer EP, Loirat D, Awada A, Cescon DW, Iwata H, Campone M, Nanda R, et al: Pembrolizumab monotherapy for previously treated metastatic triple-negative breast cancer: Cohort A of the phase II KEYNOTE-086 study. Ann Oncol 30: 397-404, 2019.

8. Voorwerk L, Slagter M, Horlings HM, Sikorska K, van de Vijver KK, de Maaker M, Nederlof I, Kluin RJC, Warren S, Ong $\mathrm{S}$, et al: Immune induction strategies in metastatic triple-negative breast cancer to enhance the sensitivity to PD-1 blockade: The TONIC trial. Nat Med 25: 920-928, 2019.
9. Ovcaricek T, Takac I and Matos E: Multigene expression signatures in early hormone receptor positive HER 2 negative breast cancer. Radiol Oncol 53: 285-292, 2019.

10. Yamauchi H, Nakagawa C, Yamashige S, Takei H, Yagata $H$, Yoshida A, Hayashi N, Hornberger J, Yu T, Chao C, et al: Societal cost-effectiveness analysis of the 21-gene assay in estrogen-receptor-positive, lymph-node-negative early-stage breast cancer in Japan. BMC Health Serv Res 14: 372, 2014.

11. Daigo Y and Nakamura Y: From cancer genomics to thoracic oncology: Discovery of new biomarkers and therapeutic targets for lung and esophageal carcinoma. Gen Thorac Cardiovasc Surg 56: 43-53, 2008.

12. Daigo Y, Takano A, Teramoto K, Chung S and Nakamura Y: A systematic approach to the development of novel therapeutics for lung cancer using genomic analyses. Clin Pharmacol Ther 94: 218-223, 2013.

13. Ishikawa N, Daigo Y, Takano A, Taniwaki M, Kato T, Hayama S, Murakami H, Takeshima $\mathrm{Y}$, Inai $\mathrm{K}$, Nishimura $\mathrm{H}$, et al: Increases of amphiregulin and transforming growth factor-alpha in serum as predictors of poor response to gefitinib among patients with advanced non-small cell lung cancers. Cancer Res 65: 9176-9184, 2005.

14. Ishikawa N, Daigo Y, Yasui W, Inai K, Nishimura H, Tsuchiya E, Kohno N and Nakamura Y: ADAM8 as a novel serological and histochemical marker for lung cancer. Clin Cancer Res 10: 8363-8370, 2004.

15. Kakiuchi S, Daigo Y, Ishikawa N, Furukawa C, Tsunoda T, Yano S, Nakagawa K, Tsuruo T, Kohno N, Fukuoka M, et al: Prediction of sensitivity of advanced non-small cell lung cancers to gefitinib (Iressa, ZD1839). Hum Mol Genet 13: 3029-3043, 2004.

16. Kato T, Daigo Y, Hayama S, Ishikawa N, Yamabuki T, Ito T, Miyamoto M, Kondo S and Nakamura Y: A novel human tRNA-dihydrouridine synthase involved in pulmonary carcinogenesis. Cancer Res 65: 5638-5646, 2005

17. Kikuchi T, Daigo Y, Katagiri T, Tsunoda T, Okada K, Kakiuchi S, Zembutsu H, Furukawa Y, Kawamura M, Kobayashi K, et al: Expression profiles of non-small cell lung cancers on cDNA microarrays: Identification of genes for prediction of lymph-node metastasis and sensitivity to anti-cancer drugs. Oncogene 22: 2192-2205, 2003.

18. Suzuki C, Daigo Y, Ishikawa N, Kato T, Hayama S, Ito T, Tsuchiya E and Nakamura Y: ANLN plays a critical role in human lung carcinogenesis through the activation of RHOA and by involvement in the phosphoinositide 3-kinase/AKT pathway. Cancer Res 65: 11314-11325, 2005.

19. Kakiuchi S, Daigo Y, Tsunoda T, Yano S, Sone S and Nakamura Y: Genome-wide analysis of organ-preferential metastasis of human small cell lung cancer in mice. Mol Cancer Res 1: 485-499, 2003.

20. Taniwaki M, Daigo Y, Ishikawa N, Takano A, Tsunoda T, Yasui W, Inai K, Kohno N and Nakamura Y: Gene expression profiles of small-cell lung cancers: Molecular signatures of lung cancer. Int J Oncol 29: 567-575, 2006.

21. Oshita H, Nishino R, Takano A, Fujitomo T, Aragaki M, Kato T, Akiyama H, Tsuchiya E, Kohno N, Nakamura Y, et al: RASEF is a novel diagnostic biomarker and a therapeutic target for lung cancer. Mol Cancer Res 11: 937-951, 2013.

22. Hayama S, Daigo Y, Yamabuki T, Hirata D, Kato T, Miyamoto M, Ito T, Tsuchiya E, Kondo S and Nakamura Y: Phosphorylation and activation of cell division cycle associated 8 by aurora kinase B plays a significant role in human lung carcinogenesis. Cancer Res 67: 4113-4122, 2007.

23. Ishikawa N, Daigo $Y$, Takano A, Taniwaki $M$, Kato $T$, Tanaka S, Yasui W, Takeshima Y, Inai K, Nishimura H, et al: Characterization of SEZ6L2 cell-surface protein as a novel prognostic marker for lung cancer. Cancer Sci 97: 737-745, 2006.

24. Kato T, Sato N, Hayama S, Yamabuki T, Ito T, Miyamoto M, Kondo S, Nakamura Y and Daigo Y: Activation of Holliday junction recognizing protein involved in the chromosomal stability and immortality of cancer cells. Cancer Res 67: 8544-8553, 2007.

25. Suzuki C, Takahashi K, Hayama S, Ishikawa N, Kato T, Ito T, Tsuchiya E, Nakamura Y and Daigo Y: Identification of Myc-associated protein with JmjC domain as a novel therapeutic target oncogene for lung cancer. Mol Cancer Ther 6: 542-551, 2007.

26. Takahashi K, Furukawa C, Takano A, Ishikawa N, Kato T, Hayama S, Suzuki C, Yasui W, Inai K, Sone S, et al: The neuromedin U-growth hormone secretagogue receptor $1 \mathrm{~b} /$ neurotensin receptor 1 oncogenic signaling pathway as a therapeutic target for lung cancer. Cancer Res 66: 9408-9419, 2006. 
27. Taniwaki M, Takano A, Ishikawa N, Yasui W, Inai K, Nishimura H, Tsuchiya E, Kohno N, Nakamura Y and Daigo Y: Activation of KIF4A as a prognostic biomarker and therapeutic target for lung cancer. Clin Cancer Res 13: 6624-6631, 2007.

28. Yamabuki T, Takano A, Hayama S, Ishikawa N, Kato T, Miyamoto $\mathrm{M}$, Ito $\mathrm{T}$, Ito $\mathrm{H}$, Miyagi $\mathrm{Y}$, Nakayama $\mathrm{H}$, et al: Dikkopf-1 as a novel serologic and prognostic biomarker for lung and esophageal carcinomas. Cancer Res 67: 2517-2525, 2007.

29. Fujitomo T, Daigo Y, Matsuda K, Ueda K and Nakamura Y: Identification of a nuclear protein, LRRC42, involved in lung carcinogenesis. Int J Oncol 45: 147-156, 2014.

30. Nguyen MH, Koinuma J, Ueda K, Ito T, Tsuchiya E, Nakamura Y and Daigo Y: Phosphorylation and activation of cell division cycle associated 5 by mitogen-activated protein kinase play a crucial role in human lung carcinogenesis. Cancer Res 70: 5337-5347, 2010.

31. Hayama S, Daigo Y, Kato T, Ishikawa N, Yamabuki T, Miyamoto M, Ito T, Tsuchiya E, Kondo S and Nakamura Y: Activation of CDCA1-KNTC2, members of centromere protein complex, involved in pulmonary carcinogenesis. Cancer Res 66: 10339-10348, 2006.

32. Hirokawa N, Noda Y and Okada Y: Kinesin and dynein superfamily proteins in organelle transport and cell division. Curr Opin Cell Biol 10: 60-73, 1998

33. Hill E, Clarke $M$ and Barr FA: The Rab6-binding kinesin, Rab6-KIFL, is required for cytokinesis. EMBO J 19: 5711-5719, 2000

34. Taniuchi K, Nakagawa H, Nakamura T, Eguchi H, Ohigashi H, Ishikawa O, Katagiri T and Nakamura Y: Down-regulation of RAB6KIFL/KIF20A, a kinesin involved with membrane trafficking of discs large homologue 5, can attenuate growth of pancreatic cancer cell. Cancer Res 65: 105-112, 2005.

35. Khongkow P, Gomes AR, Gong C, Man EP, Tsang JW, Zhao F, Monteiro LJ, Coombes RC, Medema RH, Khoo US, et al: Paclitaxel targets FOXM1 to regulate KIF20A in mitotic catastrophe and breast cancer paclitaxel resistance. Oncogene 35 : 990-1002, 2016.

36. Saito K, Ohta S, Kawakami Y, Yoshida K and Toda M: Functional analysis of KIF20A, a potential immunotherapeutic target for glioma. J Neurooncol 132: 63-74, 2017.

37. Zhang Z, Chai C, Shen T, Li X, Ji J, Li C, Shang Z and Niu Y: Aberrant KIF20A Expression is associated with adverse clinical outcome and promotes tumor progression in prostate cancer. Dis Markers 2019: 4782730, 2019.

38. Shen T, Yang L, Zhang Z, Yu J, Dai L, Gao M, Shang Z and Niu Y: KIF20A affects the prognosis of bladder cancer by promoting the proliferation and metastasis of bladder cancer cells. Dis Markers 2019: 4863182, 2019.
39. Takano A, Ishikawa N, Nishino R, Masuda K, Yasui W, Inai K, Nishimura $\mathrm{H}$, Ito H, Nakayama H, Miyagi Y, et al: Identification of nectin-4 oncoprotein as a diagnostic and therapeutic target for lung cancer. Cancer Res 69: 6694-6703, 2009.

40. Kobayashi Y, Takano A, Miyagi Y, Tsuchiya E, Sonoda H Shimizu T, Okabe H, Tani T, Fujiyama Y and Daigo Y: Cell division cycle-associated protein 1 overexpression is essential for the malignant potential of colorectal cancers. Int J Oncol 44: 69-77, 2014

41. Thang PM, Takano A, Yoshitake Y, Shinohara M, Murakami Y and Daigo Y: Cell division cycle associated 1 as a novel prognostic biomarker and therapeutic target for oral cancer. Int J Oncol 49: 1385-1393, 2016

42. Daigo K, Takano A, Thang PM, Yoshitake Y, Shinohara M, Tohnai I, Murakami Y, Maegawa J and Daigo Y: Characterization of KIF11 as a novel prognostic biomarker and therapeutic target for oral cancer. Int J Oncol 52: 155-165, 2018.

43. Shi C, Huang D, Lu N, Chen D, Zhang M, Yan Y, Deng L, Lu Q, $\mathrm{Lu} \mathrm{H}$ and Luo S: Aberrantly activated Gli2-KIF20A axis is crucial for growth of hepatocellular carcinoma and predicts poor prognosis. Oncotarget 7: 26206-26219, 2016.

44. Fontijn RD, Goud B, Echard A, Jollivet F, van Marle J, Pannekoek $\mathrm{H}$ and Horrevoets AJ: The human kinesin-like protein RB6K is under tight cell cycle control and is essential for cytokinesis. Mol Cell Biol 21: 2944-2955, 2001.

45. Tcherniuk S, Skoufias DA, Labriere C, Rath O, Gueritte F, Guillou C and Kozielski F: Relocation of Aurora B and survivin from centromeres to the central spindle impaired by a kinesin-specific MKLP-2 inhibitor. Angew Chem Int Ed Engl 49: 8228-8231, 2010

46. Labrière C, Talapatra SK, Thoret S, Bougeret C, Kozielski F and Guillou C: New MKLP-2 inhibitors in the paprotrain series: Design, synthesis and biological evaluations. Bioorg Med Chem 24: 721-734, 2016.

47. Sakai R, Morikawa Y, Kondo C, Oka H, Miyajima H, Kubo K and Uehara T: Combinatorial measurement of CDKN1A/p21 and KIF20A expression for discrimination of DNA damage-induced clastogenicity. Int J Mol Sci 15: 17256-17269, 2014.

48. Düzgün ŞA, Yerlikaya A, Zeren S, Bayhan Z, Okur E and Boyac1 I: Differential effects of p38 MAP kinase inhibitors SB203580 and SB202190 on growth and migration of human MDA-MB-231 cancer cell line. Cytotechnology 69: 711-724, 2017.

49. Ferrero H, Corachán A, Quiñonero A, Bougeret C, Pouletty $P$, Pellicer A and Domínguez F: Inhibition of KIF20A by BKS0349 reduces endometriotic lesions in a xenograft mouse model. Mol Hum Reprod 25: 562-571, 2019. 